\title{
Current Trends in Training Forensic Experts in Ukraine
}

\author{
Oleg Kurdes \\ Ph.D student, National Scientific Center \\ "Hon. Prof. M. S. Bokarius Forensic Science Institute", Ukraine \\ oleg700615@ukr.net
}

\begin{abstract}
The system of forensic expert training in Ukraine has been considered in detail. Particular attention is devoted to the need to bring the training of state forensic experts and forensic experts who are not employees of state forensic science institution to uniform administrative and legal standards, as well as to existence of outdated norms on training forensic experts, and gaps in legislation that leads to insufficient meeting of the needs of law enforcement agencies and court in objective and high-quality forensic expert conclusions.

Analysis of administrative legislation of Ukraine in terms of forensic expert training has allowed to formulate proposals to improve the activity. The focus is the need for further administrative and legal settlement of the issue of international cooperation of state specialised forensic science institution in terms of exchange of trainees with forensic science institutions of other states.

Keywords: forensic science institution, forensic expert, staff training, advanced training.

In the near future, most technologies used currently will become obsolete, and the education received more than ten years ago no longer satisfies the stated requirements. Continuous updating of knowledge and improvement of skills becomes the life rule. The issues of professional training and advanced training of forensic experts are currently relevant both for employees of state forensic science institutions and for employees who are not full-time employees of these institutions. Due to the change in forensic expert generation, training of new employees is of paramount importance. Improving methods of conducting forensic examinations and the related complexity requires centralised training of new staff, regardless of whether the forensic expert works in states forensic
\end{abstract}


science institutions or he is not a full-time employee of these institutions. The expert employment form should not affect his training.

Such scientists as E. B. Simakova-Yefremian, I. A. Petrova, N. M. Tkachenko, O. V. Agapova and S. He. Hasparian dealt with the issue of training forensic experts in Ukraine. They have made a significant contribution to construction of modern directions for development of training and retraining of forensic experts. The agenda is focused on further improvement of this activity, improvement of tactical direction of professional expert training.

Thus, E. B. Simakova-Yefremian and his colleagues draw attention to the fact that state law enforcement system is extremely interested in "training highly qualified forensic experts" considering both domestic and foreign experience. Interesting is their opinion that "effective form of international cooperation is the conduct of mutual internships of forensic experts and scholars in forensic science institutions of other states" [1, 175, 177].

N. M. Tkachenko emphasises that "training of forensic experts is one of the most important means of expert support of justice in the state, as only a professional of high scientific level is able to provide an objective conclusion based on the use of specific expertise in any type of legal proceedings" [2, 203].

I. A. Petrova was one of the first to raise the issue of the need to recreate in a new capacity a centralised system of forensic expert training and improve their skills, to create units for advanced training based on the research forensic institutions of the Ministry of Justice of Ukraine. In addition, she pointed out that such training should be mandatory for all forensic experts, regardless their work in state forensic science institutions or in business structures $[3,19]$. She also formulated the necessary requirements for a forensic expert as a "specialist of high scientific qualification who can develop new creative expert methods" $[4,79]$.

Having studied scholar opinions for determining the features of administrative and legal regulation in the field of education, O. V. Agapova concludes that "public relations that are the subject of administrative law, are regulated by means of administrative and legal regulation". At the same time, she emphasises that "education field covers a wide range of public relations, which are regulated by the norms of administrative law, as they arise in the process of exercising executive power; it is in providing educational services that public administration entities meet public needs in the education field, indicating the administrative and legal nature of such relations". She proposes to "consider regulations that are the basis of administrative and legal regulation of training of highly qualified scientific personnel by research institutions of forensic examinations" [5, 58-59].

It should be noted that I. A. Petrova drew attention to the system of stimulating forensic expert work and argued that "next to the material component should be the intangible that will determine the ability and desire of an employee for the professional development by gaining new knowledge and skills". It is impossible to disagree with her opinion about the benefits of the forensic institution "investing in human capital" that "will 
form the necessary level of staff skills" so that in the future "guarantees of sustainable development" will be provided for this institution $[6,216]$.

S. He. Hasparian determined "the need for serious organisational and methodological changes in the training of forensic expert staff". In addition, she considers "the main condition for such training [to be the] formation of a new round in the field of forensic science" and includes "regulations, organisational and structural elements of education, methodological and technological standards of education, standards and technology of initial control theoretical knowledge and practical skills of forensic experts" [7, 286].

The fundamental provisions for training of forensic experts in Ukraine are regulated by the Law of Ukraine: On Judicial Examination. Thus, in accordance with Article 8 of this Law, the management of scientific and methodological support of forensic activities and organisational and managerial principles of state specialised institutions are entrusted to ministries and other central executive bodies the management of which includes state specialised institutions performing forensic science activity [9]. From the content of this norm, it can be concluded that organisation and training of forensic experts is entrusted to the Ministry of Justice of Ukraine, the Ministry of Health of Ukraine, the Ministry of Internal Affairs of Ukraine, the Ministry of Healthcare of Ukraine, Security Service of Ukraine and the State Border Guard Service of Ukraine. state specialised institutions that perform forensic science activity.

In addition, Article 10 of the Law of Ukraine: On Judicial Examination provides that forensic experts may be persons who have the necessary knowledge to provide a conclusion on the issues under investigation. According to this article, forensic experts of both state specialised institutions and forensic experts who are not employees of these institutions may be persons who have the appropriate higher education, educational and qualification level not lower than specialist, trained in state specialised institutions. Ministry of Justice of Ukraine has been certified and qualified as a forensic expert in the respective specialisation [9].

In accordance with the requirements of Articles 10 and 21 of the Law of Ukraine: On Judicial Examination, training of forensic experts is carried out by higher education institutions by obtaining the higher educational qualification level not lower than a specialist and further obtaining the appropriate specialisation, as well as training, workshops in special institutions of relevant ministries and other central executive bodies. It should be noted that Article 21 of this Law establishes uniform requirements for training of forensic experts of state specialised institutions and professionals who are not employees of these institutions [9].

Professionals who are not employees of state specialised institutions and majoring in forensic science, except for those who have a scientific degree, according to Article 21 of the Law once every three years should undergo training in state specialised institutions of the Ministry of Justice of Ukraine according to the specialisation and confirm the level of their professional knowledge [9]. 
S. He. Hasparian draws attention to the fact that "the most advanced system, from basic education to further specialisation was introduced by the Ministry of Health of Ukraine for forensic and forensic psychiatric experts" $[8,179]$ who are majoring in forensic science or mental state examination (MSE) after internship.

Some professionals in the field of forensic science of the Ministry of Internal Affairs of Ukraine are trained differently. Thus, in the institutions of higher education of this ministry, there are faculties for training of criminalists and forensic experts. Upon graduation, graduates receive a diploma of higher education and a special permit to conduct criminalistics' examinations.

Training of forensic experts of the Ministry of Justice of Ukraine is regulated by the following regulations: the Law of Ukraine: On Judicial Examination; regulations on attestation of researchers, approved by the resolution of the Cabinet of Ministers of Ukraine No 1475 dated on August 13, 1999; regulations on the Central Expert Qualification Commission under the Ministry of Justice of Ukraine and certification of forensic experts approved by the order of the Ministry of Justice of Ukraine No 301/5 dated on March 3, 2015; procedure for assigning qualification grade of forensic experts to employees of research institutions of forensic examinations of the Ministry of Justice of Ukraine approved by the order of the Ministry of Justice of Ukraine No 3660/5 dated on December 30, 2011.

Regulations on the Central Expert Qualification Commission under the Ministry of Justice of Ukraine and attestation of forensic experts determine the procedure for training and internship of professionals intending to obtain or confirm the forensic expert qualification, and the procedure for attestation to assign and confirm the forensic expert qualification in this commission [10].

The main tasks of the Central Expert Qualification Commission (hereinafter referred to as CEQC) concerning the training of forensic expert staff, are:

1) approval of training programmes (internships) for employees of forensic science institutions of the Ministry of Justice of Ukraine (hereinafter referred to as FSI) and professionals who are not employees of state specialised institutions;

2) resolution of issues related to training of FSI employees, professionals who are not employees of state specialised institutions and intend to obtain (confirm) forensic expert qualification;

3) attestation in order to determine the level of professional training of FSI employees, professionals who are not employees of state specialised institutions and intend to obtain or confirm the forensic expert qualification;

4) consideration of the issue of assigning a forensic expert skill category to FSI employees;

5) regulating the issues of the revocation of a certificate of forensic expert qualification [10].

Training (internship) of FSI employees intend to obtain or confirm that the forensic expert qualification is carried out according to the training programme on theoretical, 
organisational and procedural issues of forensic examination by FSI or the Institute of Law and Postgraduate Education of the Ministry of Justice of Ukraine; according to the training programmes in the relevant forensic expert specialisation by FSI. Training (internship) of professional who are not employees of state specialised institutions and intend to obtain and/or confirm the forensic expert qualification is carried out according to the programme of training on theoretical, organisational and procedural issues of forensic science by Institute of Law and Postgraduate Education of the Ministry of Justice of Ukraine and FSI, who have the appropriate license to carry out educational activities in the field of advanced training according to the training programmes in relevant expert specialisation by FSI [10].

Certification of FSI forensic experts in order to assign a forensic expert skill category is carried out in accordance with "Procedure for assigning skill categories of forensic experts to employees of forensic science institutions of the Ministry of Justice of Ukraine" [11].

The Law of Ukraine: On Judicial Examination (Article 24) provides the right to state specialised institutions that perform forensic examinations to exchange trainees with forensic science institutions, etc. of other states [9]. An example of a successful reform of the system of training forensic experts is the creation of National Scientific Center "Hon. Prof. M. S. Bokarius Forensic Science Institute" (hereinafter referred to as NSC "Hon. Prof. M. S. Bokarius FSI") of a separate structural unit - the Department of Continuing Professional Development (hereinafter referred to as Department), whose main tasks are the organisation of advanced training of forensic experts in the field of postgraduate education for people with higher education in the field of 08 Law majoring in 081 Law Theoretical, organisational and procedural issues of forensic examination and training (internship) of experts in the relevant forensic expert specialisation. The department collects and verifies accuracy of documents for training, management of settlements of non-residents, sending relevant documents to the Central Expert Qualification Commission at the Ministry of Justice of Ukraine to address the issue of forensic expert qualification. In addition, Department of Continuing Professional Development of NSC "Hon. Prof. M. S. Bokarius FSI" together with another structural unit of NSC "Hon. Prof. M. S. Bokarius FSI" namely the Department of International Relations, issues invitations to study and ensure the stay of foreigners and stateless persons in Ukraine on legal grounds.

However, lack of unified administrative norms for the organisation of training directly in the state specialised institutions of the Ministry of Justice of Ukraine and document management has a negative impact on the management of the area and hinders its development. In addition, in order to improve the organisation of training and retraining of forensic experts, it is considered appropriate to work on the creation of an appropriate training manual for immediate participants in this procedure. 


\section{Conclusions}

Training of forensic experts in Ukraine in the legal context complies with administrative legislation. Professional development, retraining and advanced training are not possible without a clear regulation of the relevant legislation. In addition, given that training should be provided not only to forensic experts of state forensic science institutions and professionals who are not their full-time employees but perform the functions of forensic experts, existence of administrative law governing relations between sub authorities and citizens is mandatory.

It is currently relevant to separate from the Regulations on the Central Expert Qualification Commission under the Ministry of Justice of Ukraine and certification of forensic experts' rules on training (internships) and development with further approval by the Ministry of Justice of Ukraine of a separate Regulations on forensic expert training. It has been emphasised that further administrative and legal settlement of the issue of international cooperation of state specialised forensic science institutions in terms of exchange of trainees with forensic science and criminalistics institutions and of other states is needed.

\section{Bibliography}

\section{Journals}

1. Simakova-Yefremian, E. B., Derecha, L. M., Miasoiedov, V. V. (2018). Aktualni problemy spivrobitnytstva z orhanizatsiiamy inozemnykh derzhav u sferi sudovo-ekspertnoi diialnosti. Teoriia ta praktyka sudovoi ekspertyzy i kryminalistyky: zb. nauk. prats. Kharkiv: Pravo. 18, 175-184.

2. Tkachenko, N. M. (2018). Udoskonalennia profesiinoi pidhotovky sudovoho eksperta - vazhlyvyi faktor rozvytku ekspertnoi dydaktyky. Teoriia ta praktyka sudovoi ekspertyzy i kryminalistyky: zb. nauk. prats. Kharkiv: Pravo. 18, 203-214.

3. Petrova, I. A. (2018). Shliakhy vdoskonalennia systemy pidhotovky sudovykh ekspertiv v Ukraini. Aktualni pytannia sudovoi ekspertyzy ta kryminalistyky: zb. mater. mizh nar. nauk.-prakt. konf., prysviachenoi 95-richchiu stvorennia Kharkivskoho naukovo-doslidnoho instytutu sudovykh ekspertyz im. Zasl. prof. M. S. Bokariusa. Kharkiv: KhNDISE. 17-19.

4. Petrova, I. A. (2017). Naukova skladova u formuvanni sudovoho eksperta. Aktualni pytannia sudovoi ekspertyzy ta kryminalistyky: zb. mater. mizh nar. nauk.-prakt. konf., prysviachenoi 100-richchiu vid dnia narodzhennia doktora yurydychnykh nauk, profesora, zasluzhenoho diiacha nauky i tekhniky Ukrainy M. V. Saltevskoho. Kharkiv: KhNDISE. 78-79.

5. Ahapova, O. V. (2019). Osvitnia diialnist naukovo-doslidnykh ustanov u sferi ekspertnoho zabezpechennia pravosuddia: aktualni pytannia administratyvno-pravovoho rehuliuvannia. Visnyk KhNUVS. 2(85), 56-65.

6. Petrova, I. A. (2018). Shliakhy motyvatsii spivrobitnykiv sudovo-ekspertnykh ustanov Ukrainy. Teoriia ta praktyka sudovoi ekspertyzy i kryminalistyky: zb. nauk. prats. Kharkiv: Pravo. 18, 214-221. 
7. Hasparian, S. H. (2018). Shliakhy pidvyshchennia yakosti pidhotovky kadriv dlia sudovo-ekspertnykh ustanov Ministerstva yustytsii Ukrainy. Teoriia ta praktyka sudovoi ekspertyzy i kryminalistyky: zb. nauk. prats. Kharkiv: Pravo. 18, 281-287.

8. Hasparian, S. H. (2019). Mistse administratyvno-pravykh norm u pravovomu rehuliuvanni kadrovoho zabezpechennia sudovo-ekspertnykh ustanov Ukrainy. Teoriia ta praktyka sudovoi ekspertyzy i kryminalistyky: zb. nauk. prats. Kharkiv: Pravo. 20, 175-187.

\section{Internet resources}

9. Pro sudovu ekspertyzu: Zakon Ukrainy vid 25.02.1994 r. № 4038-KhII (zi zminamy ta dopovnenniamy). Vidomosti Verkhovnoi Rady Ukrainy. 1994. № 28. Available from: https://zakon.rada. gov.ua/laws/show/4038-12 [07.01.2021].

10. Pro zatverdzhennia Polozhennia pro Tsentralnu ekspertno-kvalifikatsiinu komisiiu pry Ministerstvi yustytsii Ukrainy ta atestatsiiu sudovykh ekspertiv. Nakaz Ministerstva yustytsii Ukrainy. Vid 03.03.2015, № 301/5. Available from: https://zakon.rada.gov.ua/laws/card/z0249-15 [07.01.2021].

11. Pro zatverdzhennia Poriadku prysvoiennia kvalifikatsiinykh klasiv sudovykh ekspertiv pratsivnykam naukovo-doslidnykh ustanov sudovykh ekspertyz Ministerstva yustytsii Ukrainy. Nakaz Ministerstva yustytsii Ukrainy. Vid 30.12.2011, № 3660/5. Available from: https://zakon.rada. gov.ua/laws/show/z0002-12 [07.01.2021]. 